\title{
Gruppeterapi ved legemiddelavhengighet
}

\author{
Ved Avdeling for rusmedisin ved Haukeland universitetssykehus utvikler vi et poliklinisk gruppebehandlings- \\ tilbud til personer som ønsker hjelp til gradvis å trappe ned og seponere vanedannende legemidler. Målset- \\ tingen er å erstatte medikamenter med mer hensiktsmessige strategier for å kunne hanskes med ulike typer
} ubehag.

I flere artikler i Tidsskriftet er det pekt på behovet for gode og tilstrekkelige behandlingstilbud til medikamentavhengige (1-3). Etablering og utvikling av slike tilbud er i tråd med intensjonene i Opptrappingsplan for rusfeltet, som ble introdusert i 2008 (4). Gruppeterapi ved rus- og avhengighetstilstander tilbys ved flere rusbehandlingsinstitusjoner i Norge (2). Medikamentavhengige får som regel gruppebehandling sammen med andre grupper av rusmiddelbrukere. Særskilte tilbud til medikamentavhengige er imidlertid blitt etterlyst (2).

Poliklinikk for vanedannende legemidler ble etablert som en seksjon under Avdeling for rusmedisin ved Haukeland universitetssykehus våren 2010. Utgangspunktet for vår gruppebehandlingsmodell er at medikamentavhengige utgjør en egen kategori med spesielle behandlingsbehov og at de har en annen identitet enn øvrige grupper av rusmiddelavhengige (2).

\section{Målgruppe og målsetting}

Behandlingstilbudet retter seg mot dem som er blitt avhengig av vanedannende legemidler. Mange pasienter er ikke klar over at langvarig bruk er med på å vedlikeholde plagene og er heller ikke blitt tilstrekkelig orien-

Tabell 1 Psykoedukasjonstemaer

\begin{tabular}{|c|c|}
\hline Sesjon & Temaer \\
\hline 1 & $\begin{array}{l}\text { Presentasjon av behandlings- } \\
\text { opplegget. Hva er oppmerksomt } \\
\text { nærvær? }\end{array}$ \\
\hline 2 & $\begin{array}{l}\text { Avhengighet av vanedannende lege- } \\
\text { midler. Virkninger og bivirkninger }\end{array}$ \\
\hline 3 & $\begin{array}{l}\text { Hvordan oppstår vonde sirkler del } \\
\text { I - den bio-psyko-sosiale modellen }\end{array}$ \\
\hline 4 & $\begin{array}{l}\text { Hvordan oppstår vonde sirkler del II } \\
\text { - den kognitive modellen }\end{array}$ \\
\hline 5 & $\begin{array}{l}\text { Hvordan oppstår muskulære spen- } \\
\text { ninger? }\end{array}$ \\
\hline 6 & $\AA$ akseptere virkeligheten slik den er \\
\hline 7 & Gode råd for bedre søvn \\
\hline 8 & Følelser \\
\hline 9 & Selvfølelsen \\
\hline 10 & $\begin{array}{l}\text { Kommunikasjon og samvær med } \\
\text { andre }\end{array}$ \\
\hline 11 & Forebygging av tilbakefall \\
\hline 12 & Veien videre \\
\hline
\end{tabular}

tert om en slik effekt. For andre kan det være vanskelig å erkjenne og akseptere at det medikamentet som hjalp til å begynne med, etter hvert har begynt å forsterke plagene.

Pasienten kalles først inn til en kartleggingssamtale for vurdering av egnethet og motivasjon for gruppebehandlingstilbudet. Det er viktig å anerkjenne pasientens plager og bakgrunn for å bruke vanedannende legemidler, samtidig som det må formidles håp om at det er mulig å slutte med slike legemidler og erstatte dem med mer hensiktsmessige mestringsstrategier.

\section{« skulle hjelpe pasienten til å bryte vanemessige reaksjoner på suget etter medikamenter når nedtrappingen starter»}

\section{Individuell nedtrappingsplan}

Lege ved poliklinikken har hovedansvar for å utarbeide en skriftlig nedtrappingsplan sammen med pasienten og behandlingsansvarlig psykolog. Nedtrappingsplanen, som går over 12 uker, skal tre i kraft når selve gruppebehandlingen starter. Planen innebærer i første omgang stabilisering av medikamentinntaket til faste tidspunkter, ikke etter behov. Det anbefales at dosereduksjonen er på i gjennomsnitt $10 \%$ i uken. I starten kan nedtrappingen gå raskere. Når det nærmer seg seponering, vil mange ha behov for langsommere nedtrapping. En tommelfingerregel er at pasienten unngår å trappe opp igjen, men heller forlenger intervallene.

Fastlegen får en kopi av planen og eventuelle senere revisjoner og er den som har ansvar for forskrivning av legemidlene. Fastlegen skal følge pasienten opp i etterkant av behandlingen. Pasienten signerer en behandlingskontrakt som har som mål å ansvarliggjøre ham/henne med tanke på egenaktivitet og samarbeid underveis $\mathrm{i}$ behandlingsprosessen.

\section{Behandlingsmodell}

Gruppebehandlingen tar utgangspunkt i kognitiv atferdsterapi. Identifisering og utfordring av negative tankemønstre knyttet til symptomer og ubehag er et sentralt element. «Mindfulness», eller øvelser i oppmerksomt nærvær, har en fast plass på gruppesamlingene. Integrering av oppmerksomt nærvær i behandlingen av ulike tilstandsbilder er i tråd med nyere utvikling innenfor kognitiv atferdsterapeutisk behandling (5). En slik tilnærming har vist seg å ha effekt også på avhengighetstilstander (6). Å være oppmerksomt nærværende innebærer å observere alle opplevelser og erfaringer med en aksepterende og åpen holdning, uten å følge impulser om å endre eller flykte fra det som utspiller seg, selv om det er ubehagelig eller uønsket (7).

Øvelsene er ment å skulle hjelpe pasienten til å bryte vanemessige reaksjoner på suget etter medikamenter når nedtrappingen starter. Samtidig er hensikten at deltakerne skal få erfaring med at systematisk trening i oppmerksomt nærvær kan øke bevisstheten omkring egne valg og handlinger øyeblikket.

\section{Behandlingsmanual - rammer og innhold}

Behandlingen gis i lukkede grupper på opptil åtte deltakere og går over 12 uker. Det er to behandlere i hver gruppe, hvorav ansvarlig behandler er psykologspesialist. Gruppemøtene foregår på dagtid en fast dag i uken og varer 2,5 timer inkludert pause.

Sesjonene er organisert med faste poster som gjentar seg fra gang til gang, noe som skaper forutsigbarhet for deltakerne. Det avholdes tre oppfølgingsmøter, henholdsvis fire, åtte og 36 uker etter avsluttet behandling.

Sesjonene starter og avsluttes med øvelse i oppmerksomt nærvær. Øvelsene foregår sittende og har en varighet på mellom 15 og 20 minutter.

\section{Statusrapport for nedtrapping}

Den enkelte deltaker forteller gruppen hvor langt hun/han er kommet i sin nedtrappingsplan. Behandlerne har kopi av hver enkelt plan og noterer status for hver pasient. Jus- 
teringer og endringer av planen underveis i behandlingsforløpet gjøres i samarbeid med lege ved poliklinikken. Vår erfaring er at slik individuell oppfølging i samlet gruppe bidrar til at deltakerne ansvarliggjøres til å følge planen.

\section{Psykoedukasjon}

Undervisningen gis som powerpointpresentasjon, og deltakerne får utdelt papirversjonen av presentasjonen til hvert tema (tab 1). Materiellet samles i den enkeltes arbeidsmappe, som skal fungere som et «oppslagsverk» som deltakerne kan gå tilbake til og slå opp i ved behov. Psykoedukasjonstemaene tar utgangspunkt i en biopsyko-sosial forståelsesmodell (8), der bevisstgjøring av det kompliserte samspillet mellom ulike forsterkende og vedlikeholdende faktorer knyttet til ubehagelige symptomer står sentralt.

\section{Hjemmeoppgaver}

Hjemmeoppgaver blir gitt muntlig og skriftlig til hvert møte, og innebærer at deltakerne skal reflektere over sin egen situasjon og komme med forslag til alternative handlingsmåter for å takle symptomer og ubehag. De oppfordres til gradvis å eksponere seg for det som oppleves som ubehagelig. Hensikten er å få ny erfaring med og toleranse for de ubehagelige symptomene. Hjemmeoppgavene blir introdusert og gjennomgått i plenum, og deltakerne deler sine tanker og erfaringer med de andre i gruppen (ramme 1).

\section{Utbytte av behandlingen}

Så langt er fire behandlingsforløp gjennomført. Deltakerne er en sammensatt gruppe når det gjelder alder, bakgrunn og funksjonsnivå. De fleste har stått på vanedannende legemidler over mange år, noen så lenge som 30 år. Det synes å være en overvekt av personer som sliter med smerter og ulike angstsymptomer. Totalt er 30 pasienter blitt inkludert i fire grupper. 17 har fullført behandlingen. Av disse 17 har ti seponert legemidlet/ legemidlene i løpet av 12-20 uker.

Av dem som ikke har klart å seponere, kjenner vi ikke til at noen har gått opp i dosering eller har falt tilbake til utgangspunktet. Deltakerne opplever at behandlingen har gitt dem noen redskaper som hjelper dem å takle ubehag, og at øvelser i oppmerksomt nærvær er en hjelp til å stå i det som er ubehagelig.

\section{Videreutvikling \\ av behandlingstilbudet}

Til tross for individuelle vurderings- og forberedelsessamtaler opplever vi likevel at mange trekker seg eller uteblir fra behandlingen. Behandlingsfrafall kan henge sammen med manglende motivasjon og for dårlig forberedelse på hva legemiddelnedtrapping innebærer.

Økt oppmerksomhet omkring stabilisering av medikamentinntaket før behandlingsstart kan muligens forebygge noe av det frafallet som skjer. Stabilisering som forberedelse til nedtrapping og gruppebehandling kan være et oppnåelig mål pasienten og fastlegen kan jobbe frem mot. Pasienten vil trenge informasjon om hvorfor en slik stabilisering er en fordel ved nedtrapping, og eventuelt kan det utarbeides skriftlig materiale som pasienten får med seg fra vurderingssamtalen.

\section{Linn-Heidi Lunde}

liheilu@hotmail.com

Svein Skjøtskift

Poliklinikk for vanedannende legemidler

Avdeling for rusmedisin

Haukeland universitetssykehus

Linn-Heidi Lunde (f. 1959) er cand.psychol. og ph.d. og spesialist i klinisk psykologi. Hun er seksjonsleder ved Poliklinikk for vanedannende legemidler

Ingen oppgitte interessekonflikter.

Svein Skjøtskift (f. 1955) er spesialist i psykiatri og overlege ved Avdeling for rusmedisin. Han er medlem av styret i Norsk forening for rus og avhengighetsmedisin.

Ingen oppgitte interessekonflikter.

\section{Ramme 1}

Hjemmeoppgave til andre samling å sette opp mål for behandling/ endring

- Tenk igjennom hvilke mål og verdier du har og hvordan du ønsker å leve livet ditt uten medikamenter. På hvilke måter står det ubehaget du er plaget med i veien for disse målene? Går de an å tenke seg at målene kan nås til tross for ubehaget, eller kan du endre på målene for å tilpasse disse til den situasjonen du har?

- Tenk igjennom hva du ønsker å oppnå ved deltakelse i gruppebehandlingen. Sett opp et hovedmål for det du ønsker å fokusere på ved din situasjon. Sett opp to mindre mål (delmål) som leder frem mot hovedmålet. Målene må være så konkrete og spesifiserte som mulig, og de skal være tidsavgrenset

Litteratur

1. Mouland G. Praktiske råd om nedtrapping av benzodiazepiner. Tidsskr Nor Lægeforen 2001; 121 2394-5.

2. Nordlie E, Tøyvik T, Aasland OG. Behandlingstilbud for medikamentavhengige. Tidsskr Nor Lægeforen 2002: 122: 2455-7.

3. Torper J, Steine S. Seponering av B-preparater hvordan opplever brukerne det? Tidsskr Nor Lægeforen 2004; 124: 2342-4.

4. Helsedirektoratet. Opptrappingsplan for rusfeltet: Statusrapport for 2008. Rapport nr: 15-1660. Oslo: Helsedirektoratet, 2009

5. Hayes SC. Acceptance, mindfulness, and values: new directions in behavior therapy and cognitive behavior therapy. Annu Rev Clin Psychol 2011; 7: $141-68$.

6. Zgierska A, Marcus MT. Mindfulness-based therapies for substance use disorders: Part 2. Subst Abuse 2010; 31: 77-8.

7. Baer RA. Mindfulness training as a clinical intervention: a conceptual and empirical review. Clin Psychol Sci Pract 2003; 10: 125-43.

8. Sharp TJ. Chronic pain: a reformulation of the cognitive-behavioural model. Behav Res Ther 2001: 39: 787-800.

Mottatt 21.10. 2011, første revisjon innsendt 13.12. 2011, godkjent 22.12. 2011. Medisinsk redaktør Are Brean. 